\title{
A nervus ulnaris könyöktáji visszatérő ficama
}

\author{
DR. CSONKA CSABA, DR. NAGY OLIVÉR, DR. VARGA VILMOS, \\ DR. KOPINEC ANDRÁS
}

\section{ÖSSZEFOGLALÁS}

A szerzők egy könyöktáji nervus ulnaris luxatio miatt operált betegük esetét ismertetik. Elemzik a lehetséges keletkezési mechanizmust. Mútéti megoldásként a szokásos ulnaris antepozíció helyett az idegnek a cubitalis csatornába történő visszarögzítését végezték, megelőzendő a sportolás közben bekövetkező direkt idegsérülés lehetőségét. Az esetet ritkasága miatt tartják bemutatásra érdemesnek.

Kulcsszavak: $\quad$ Ficam; Könyöksérülés; Nervus ulnaris; Recidiv sérülés;

Cs. Csonka, O. Nagy, V. Varga, A. Kopinec: Recurrent dislocation of the ulnar nerve at the elbow

The authors present the case of their patient operated due to dislocation of the ulnar nerve at the elbow. They analyze the possible formation mechanisms. As surgical solution they opted for the fixation of the nerve back to the cubital canal instead of the usual ulnar anterior transposition in order to prevent the possibility of direct nerve damage occurring during sport activity. The case presented is considered worthwhile due to rare occurrence.

Key words: $\quad$ Dislocations - Surgery; Elbow - Injuries; Recurrence;

Ulnar nerve - Surgery; 


\section{BEVEZETÉS}

A könyök medialis felszínén jelentkező panaszok sokszor okoznak diagnosztikus problémát. Az esetek zömében medialis epicondylitis vagy a nervus ulnaris neuritise miatt konzervatív kezelés, vagy az ulnaris ideg antepozíciója történik. Esetünkben a gondos klinikai vizsgálattal a nervus ulnaris recidív ficamát találtuk. A könyök minden 60 fokot meghaladó flexiója esetén a cubitalis csatornából az epicondylus medialis humerin „átugorva" pattanó fenomen kíséretében a nervus ulnaris elhagyta a cubitalis csatornát, majd a könyök extenziója közben oda visszatért. A fiatal sportoló betegünknél az elváltozás általa nem észlelt körülmények között, a vizsgálatra jelentkezés előtt másfél évvel kezdődött, és kezdetben panaszokat nem okozott. Vizsgálatra a kéz élen és a kisujjon jelentkező zsibbadás, érzészavar miatt jelentkezett.

\section{ESETBEMUTATÁS}

V. E. 19 éves férfi beteg 2014. május 16-án jelentkezett szakrendelésünkön azzal a panaszszal, hogy körülbelül másfél éve jobb könyökében, hajlítás közben roppanást - pattanást érez. Az utóbbi 2-3 hónapban a pattanást követően, hajlított könyök helyzetben a tenyere és a kéz éle zsibbadni kezd. A könyök kinyújtásakor a roppanás-pattanás ismétlődik, és a zsibbadás megszűnik.

$\mathrm{Az}$ anamnézis felvétele közben kiderült, hogy a beteg igazolt másodosztályú kézilabda kapus. Sportolás közben sokszor éri a kezét, alkarját nagy erejű valgus irányú elmozdulást okozó erőhatás.

Megvizsgálva, a jobb könyök medialis felszínén, 60 fokos könyök flexióban az ulnaris ideg a cubitalis csatornából az epicondylus medialis humeri elé luxálódik. A könyök 60 fokos hajlított helyzetétől a teljes flexióban az ideg az epicondylus medialis humeri előtt volt tapintható, majd a könyök extenziójára az ideg a cubitalis csatornába reponálódott. Ez a jelenség minden könyökízületi flexióban ismétlődött.

\section{Neurológiai szakorvosi vizsgálat}

Jelzett ulnaris hypaesthesia észlelhető az alkar alsó felszínén és a kisujj területén. A könyök hajlítására a zsibbadás fokozódik. A kisujj adductiós ereje megtartott.

\section{Diagnózis}

Részleges jobb nervus u!naris laesio (szen!. zoros) az ulnaris cubitalis csatorna területén.

Aktív fizikoterápiás kezelést folytattunk (éjszakai gipszrögzítés, szelektív ingeráram) hat hétig. $A$ beteg panaszai nem csökkentek, ezért mútét mellett döntöttünk.

Mútét 2014. június 16-án. Aktív vértelenségben ívelt metszés a jobb könyök medialis felszínén. A nervus ulnarist az epicondylus medialis humeri előtt találjuk (1. ábra). A cubitalis csatorna proximalis részét a musculus anconeus epitrochlealis foglalja el, amely az ideget a csatornából medial felé subluxálja. A musculus triceps medialis feje kissé medialisan helyezkedik el, hypertrophiás (2. ábra). Az izmokat reszekáljuk. Az idegen egy keskeny "gallért" meghagyva, ennél fogva a csatornába visszarögzítjük (3. ábra). Az idegen degeneráció jelét, leszorítást nem látunk. Mozgáspróbát végzünk. Az ideg a csatornában bent marad, maximális flexióra sem luxalódik. A sebet szívó drén felett zárjuk. A végtagot magas dorsalis gipszsínben rögzítettük.

A posztoperatív szak eseménytelen volt. Varratszedés egy hét múlva történt. $A$ beteg a mútét után az eddig is meglévő - az ulnaris ideg beidegzési területének megfelelően jelentkező - zsibbadás fokozódásáról számolt be. Sebe gyógyult. Három hét után gipszét eltávolítottuk, majd aktív fizikoterápiát, szelektív ingeráram kezelést kezdtünk. B vitamin komplexet kapott. A kezelés hatására a zsibbadás megszűnt. A sport-tevékenység folytatását 12 hét után engedtük meg. Az ideg luxatiója - hat hónappal a mútét után végzett kontrollon nem volt észlelhető. 


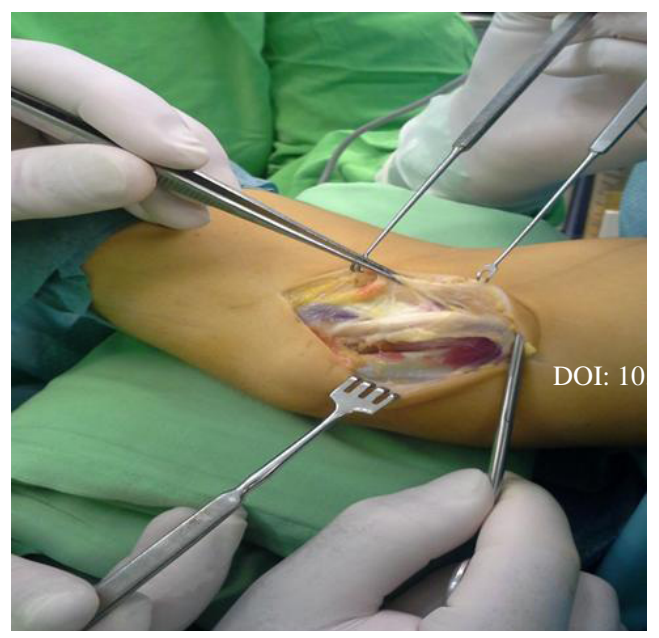

1. ábra A bör megnyitása után a nervus ulnaris az epicondylus medialis humeri elött helyezkedett el

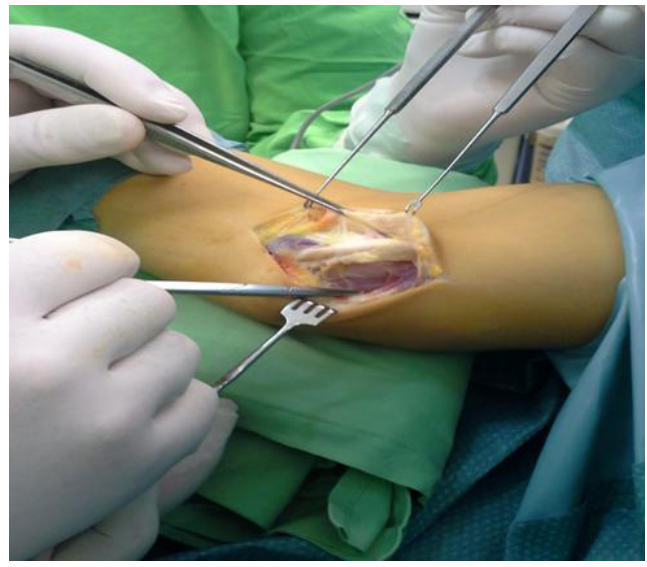

2. ábra Az olló hegyénél látható a cubitalis csatornát részben az anconeus izom, részben a triceps medialis feje kitölti

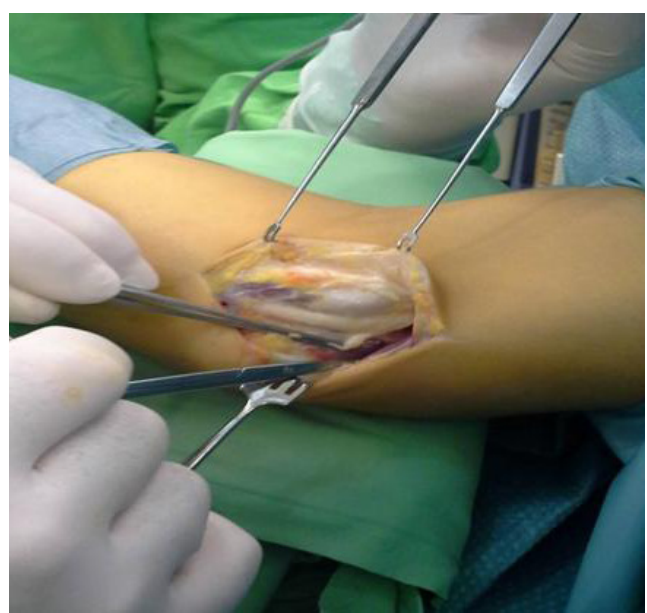

3. ábra A szabaddá tett nervus ulnarist a cubitalis csatornába a „gallérnál” fogva visszarögzítjük 


\section{MEGBESZÉLÉS}

Elsőként Childress (cit. 1) 1956-ban számolt be az ulnaris ideg subluxatiójáról. 1000 egészséges személy vizsgálatánál azt találta, hogy a vizsgáltak 16,2\%-a mutatott nervus ulnaris subluxatiót. Közülük $21 \%$-nak voltak panaszai.

Grevsten (2) a nervus ulnaris luxatióját két csoportra osztotta. Az "A" csoportba tartozó esetekben az ideg a medialis epicondylus humeri csúcsáig luxálódik. A „B” csoportba tartozó esetekben az ideg az epicondyluson átugorva az előtt található. Esetünk a B csoportba tartozott. A mútéti feltárás közben láttuk, hogy az ideg az epicondylus előtt helyezkedett el.

Spinner (9) szerint az ulnaris ideg subluxatiójában különböző etiológiai okok játszhatnak szerepet:

1. a flexor carpi ulnaris retinaculum lazasága,

2. az epicondylus medialis humeri hypoplasiája,

3. izomanomáliák,

4. poszttraumás elváltozások.

Richard (6) közleményében a muscularis anomáliák közül a musculus triceps medialis fejének dislocatióját és egy atavisztikus izom, a musculus anconeus epitrochlearis meglétével magyarázta a luxatio kialakulását.
Esetünkben is triceps izomanomáliát és atavisztikus izmot, a musculus anconeus epitrochlearis meglétét észleltük. Az anconeus izom a cubitalis csatorna proximalis részét kitöltve a musculus triceps medialis feje pedig az ideget a csatornából mediál felé taszítva együttesen okozta az ideg luxatióját. Mint az ábránkon is látható (2. ábra) a triceps medialis feje jól fejlett volt, de ez önmagában véleményünk szerint riern okozhatta a re!vus uirraris luxatióját. A mútét közben elvégzett mozgáspróba alkalmával a triceps medialis fejének luxatiója nem volt megfigyelhető.

Összefoglalva: a szerzők többsége $(3-5,7,8,10)$ mútéti megoldásnak az ideg antepozícióját és az izomanomália rendezését javasolja. Esetünkben, tekintettel betegünk sporttevékenységére, amelynél az anteponált ideg rendszeres direkt erőbehatásnak lett volna kitéve - a kézilabda ütésének - az ideget a rajta hagyott "gallérral" a csatorna proximalis részét kitöltő anconeus izom és a triceps medialis fejének részleges reszekciójával szabaddá tett cubitalis csatornába visszarögzítettük (3. ábra).

Esetünket ritkasága, differenciáldiagnosztikai érdekessége és az általánostól eltérő műtéti megoldása miatt tartottuk közlésre érdemesnek.

\section{IRODALOM}

1. Dreyfuss U., Kessler I.: Snapping elbow due to dislocation of the medial head of the triceps. J. Bone Joint Surg. 1978. 60-B. (1): 56-57.

2. Grevsten S., Lindsjö U., Olerud S.: Recurrent ulnar nerve dislocation at the elbow. Acta Orthop. Scand. 1978. 49. $151-153$.

3. Hager D., Schöffl H.: Traumatisch bedingte Luxation des N. ulnaris. Unfallchirurg. 2001. 104. 1186-1188.

4. Kovalkovits I., Krasznai I.: A nervus ulnáris habituális luxatiója. Magyar Traumatológia Ortopédia Helyreállitó Sebészet, 1977. 20: 111-113.

5. Parisien S., Kaplan J.: A case of recurrent symptomatic dislocation of the ulnar nerve at the elbow. Orthopedics. 1982.5. (10): 1323-1326.

6. Richard J. M., Messmer C., Wray W. H., Garrigues G. E., Goldner R. D., Ruch D. S.: Management of subluxating ulnar nerve at the elbow. Orthopedics. 2010. 33. (9): 672-678.

7. Rolfsen L.: Snapping triceps tendon with ulnar neuritis. Acta Orthop. Scand. 1970. 41. 74-76.

8. Spinner R. J., O'Driscoll S. W., Jupiter J. B., Goldner R. D.: Unrecognized dislocation of the medial portion of the triceps: another cause of failed ulnar nerve transposition. J. Neurosurg. 2000. 92. 52-57.

9. Spinner R. J., Goldner R. D., Carolina D. N.: Snapping of the medial head of the triceps and recurrent dislocation of the ulnar nerve. J. Bone Joint Surg. 1998. 80-A. (2): 239-247.

10. Xarchas K. C., Psillakis I., Koukou O., Kazakos K. J., Ververidis A., Verettas D. A.: Ulnar nerve dislocation at the elbow: Review of the literature and report of three cases. Operat. Orthop. J. 2007. 1. 1-3.

\section{Dr. Csonka Csaba}

3120 Somoskőújfalu, Ifjúság út 67.

Tel: 06-30-9789734

E-mail:csonkacsaba55@gmail.com 